\title{
A Study the effect of Biofertilizer Azotobacter Chroococcum on the Growth of Mulberry Cropmorus Indica L. and the Yield of Bombyx Mori L
}

\author{
Moorthi M. ${ }^{1}$, Senthilkumar A. ${ }^{2}$, Thangaraj A. ${ }^{3 *}$ \\ ${ }^{1}$ Assistant Professor, Department of Zoology, AVC College (Autonomous), Mayiladudurai, Tamil Nadu, India \\ ${ }^{2,3 *}$ Assistant Professor, Department of Zoology, Chikkaiah Naicker College, Erode, Tamil Nadu, India
}

\begin{abstract}
The present study was carried out on the effect of biofertilizer Azotobacter chroococcumon the growth of mulberry plantMorusindica L. and larvalweight, cocoon weight, shell weight, shell ratio and effective rate of rearing (ERR) and length of silk filament of the Bombyxmori. Based on growth of mulberry plant, larval weight and the effect of Azotobacter biofertilizer on length of silk filament was more in treated and which was found to be statistically significant at $P<0.05$ level than control. Cocoon weight, shell ratio, shell weight and ERR were also in an elevated trend in treatment than the control $(P<0.01)$ one. In the present study, the use of biofertilizer A.chroococcum has reduced man power and time duration and has also reduced the usage of chemical fertilizer which could curtail the expenses of the farmers.
\end{abstract}

Keywords-Biofertilizer, Azotobacter chroococcum, Morusindica, Bombyxmori.

\section{INTRODUCTION}

Sericulture is one of the most beneficial agro-based cottage industries, which has given maximum returns to the farmers. The rearing of silkworm is an important aspect of sericulture industry. Leaves of different maturity are recommended for feeding the different larval instars of BombyxmoriL.(Sudhakaret al., 2000 and Rajaramet al., 2013).

Biofertilizers possess a number of advantages to the synthetic fertilizers which do not have any harmful effect and do not pose any environmental hazards. Mainly application of biofertilzers in mulberry cultivation is to save $50 \%$ of chemical fertilizers, cost of production was very low thereby improving the cost benefit ratio, and it has given a good yield of cocoon and good quality of silk. The use of biofertilizers has been reported to be a cheap, safe alternative to chemical fertilizers and also promotes growth and yield of plants by supplying nutrients in available form, provides resistance against pests and diseases and strengthens soil structure (Sudhakaret al.
(2000), Nair and Chandra(2001) and Sharma (2002). VAM fungi, Azotobacter, Azospirillum and phosphate solubilising bacteria are commonly applied biofertilizers in horticultural crops (FatemehZaredostet al.,2014).

One of the dominant non-symbiotic nitrogen fixing heterotrophic bacteria in mulberry plant is Azotobacterchroococcum as it has highest rate of oxygen uptake than any of the living organisms. Azotobacterbiofertilizer is the "microbial inoculant" and it is the bacterial preparation of the live A. chroococcum blended with carries material like lignite, peat soil and charcoal in powdered form (Choudhury, 1989). It has been capable of supplying nitrogen to the plants through biological nitrogen fixation and enhances plant growth by producing growth hormones and vitamins and the good yield of silk. Subbarayappaet al. (1992)and Trivedi and Bhattacharya (1993) have been revealed that application of biofertilizerAzotobacter produces hormones and vitamins such as nicotinic acid, panthothenic acid, pyridoxine, biotin, heteroauxin and gibberellin which were improved the plant growth and cocoon ratio.

Only few studies have been conducted on the effect of Azotobacterbiofertilizer in mulberry growth on larval development, cocoon and silk production. To achieve the above need, this piece of work on the effect of biofertilizerA. chroococcumon growth of mulberry, silkworm larval growth, cocoon production, shell weight, shell ratio and filament length was carried out.

\section{MATERIALS AND METHODS}

Mulberry plant MR2 variety:

The variety of Mulberry plant MR2(Mildew Resistant Variety -2) was taken for the present investigation which was placed in Lakshmi Nagar, Erode District of Tamil Nadu, India. The study area was clayeysoil; the range of $\mathrm{pH}$ was 6.5 to 7.5. The allotted spacing for cultivation was $3 \mathrm{ft} \times 3 \mathrm{ft}$ and unit area for the study was $430 \mathrm{sq} \mathrm{ft}$.

Biofertilizer inoculation: 
Plants were inoculated with biofertilizer A. Chroococcum which was in powdered form and was purchased from commercial market (T.Stanes and Company Limited, Coimbatore, Tamil Nadu, India). Quality standard have been setup for Azotobacter by the BIS. The mulberry plant was implanted on test plot and irrigation wascarried out for 7 days of intervals. On 5th day the mulberry plant was treated with farm yard manure(FYM) and following that on 15th day mulberry plant applied with Biofertilizers Azotobacter chroococcum.

Eggs of Silk Moth:

The eggs of Bombyxmori L. (Commercial hybrid MysxNB ${ }_{4} \mathrm{D}_{2}$ in bivoltine race Kalimpong-A) were taken for the present study. The maximum temperature was found to $28^{\circ} \mathrm{C}$ and the minimum temperature was $23^{\circ} \mathrm{C}$ and relative humidity was fluctuates between $85 \%$ and minimum $70 \%$ for different larval instars (Table 1).

\section{Experimental method:}

Silk worm rearing method was followed by Krishnaswamyet al. (1988). Each trial consisted of 3 replicates with 600 larvae for control and treatments. Estimation of the single leaf weight, total leaf weight, larval weight, and cocoon weight was done by the methods of RamRaoand Kodandaramaiah(2007); shell weight and shell ratio were calculated by the methods of Sonwalkar (1991); the length offilament was measured by the meter scale and recorded (Srinivasan, 1980) and all the parameters were recorded and statistical analysis was carried out to test the level of significance.

\section{RESULTS AND DISCUSSION}

In the present investigation, the effect of biofertilizer on mulberry was observed and recorded from 3 trials such as 30, 60 and 90 days of crops (Table 2). All the parameters which were presented in the table were found to be statistically significant over the control $(\mathrm{P}<0.05$ and $\mathrm{P}<0.01)$.

In the present study, the effect of A.chroococcum for the growth of mulberry leaves was in an enhancing trend which was evidenced in the weight of the treated leaves over the control. The biofertilizerA. chroococcumincreased the growth of mulberry plant which may be due to its nitrogen fixing property which might have increased the nitrogen availability of the soil and may be due to the presence of growth promoting substances like auxins, cytokinins, nicotinic acid, thiamine etc. in the biofertilizers. In addition to this, chlorophyll and sugar content produced by Azotobacter which might have increased the quality of nutrients taken by the mulberry leaves also.This is in agreement with the findings of Das et al. (1994) and Bose et al. (1995) who all showed an increase in the leaf weight of mulberry due to biofertilizers (Azotobacter) application to the soil.
Further, the present study was in confirmation with the work of Sudhakaret al. (2000) who also reported that addition of Azotobacter was significantly promoted greater yield than that given recommended dose of nitrogen.Dattaet al. (2009) observed that the biofertilizer Azophos was increased the level of macronutrients on the growth, physiology and productivity of Brassica campestries.Similar findings were also observed by Nithyaet al. (2011).

In the present study, increasing level of plant growth and best quality of leaves were observed. This may be due to the inoculation of Azotobacter in soil and roots of mulberry, which boosts the requirements of nitrogen in significant level. Sreeramaluet al. (2000) have also reported inoculation of A.chroococcum and Glomus fasciculatum improves the growth and yield of sunflower under field condition and saves nitrogen and phosphate fertilizers application.The continuous production of mulberry for a long time results in gradual reduction of leaf yield and quality. This lacuna can be improved through application of organic manures, fertilizers and bio fertilizers with ideal water management (Earanna and Govindan, 2002). Similar study was also reported by Suman Kashyap et al. (2004). Mirzakhaniet al. (2009) reported that Azotobacter enhanced the available nitrogen in the soil which could enhance the yield in safflower.

In the present study, Azotobacter promoted the weight of larvae, cocoon and shell and shell ratio (Table 2) over the control. This efficient growth from the above results is in conformity with the findings of Nagarajanet al. (1986) who have showed an increase in the larval weight and cocoon characters due to the application of biofertilizer Azotobacter. This increase in silkworm larval and cocoon weight may be due to the increase in the succulent nature of mulberry leaves because of due to Azotobacter application with less fibre and higher mineral contents which presumably stimulated the metabolic activities of silkworm resulting in improvement of larval, cocoon, shell weight and shell ratio.

In the present study, the effective rate of rearing (ERR) had been found to be increased in treated biofertilizer than that of the control (Table 2). Similar results were reported by Rajany (1998) who applied biofertilizer Azotobacter, which might have accelerated the leaf growth thereby the growth of silkworm larvae.

In the present work, an increased silk filament length was observed in the treated leaves fed cocoon over the control. The present study was in confirmation with the work of Sharma (1987).This increase in the silk filament length may be due to the indirect influence of high protein content of the leaves growth on biofertilizer Azotobacter applied soil on which the larvae fed.In the present investigation, enhancement of all the parameters might be 
due to the application of Azotobacter which might have directly influenced the increase in growth of the mulberry plants thereby indirectly enhancing the growth of silkworm larvae and ultimately leading to an increase in the cocoon weight, shell weight, shell ratio, effective rate of rearing and silk filament length.

\section{REFERENCES}

[1] Bose, P.C., SenRatna and R.K. Datta: Effect of foliar application of micronutrient to mulberry on the rearing performance of silk worm Bombyxmori L. J. Seric.,3 (1), 1-5 (1995).

[2] Choudhury, P.C.: The use of biofertilizers in Mulberry cultivation. Indian Silk.,30 (8), p 11 (1989).

[3] Das, P.K., P.C. Choudhury, A. Ghose, R.S. Katiyar, V.B. Mathur and R.K. Datta: Use of Azotobacterbiofertilizers in mulberry cultivation. Indian Silk.,31 (10), 43-45 (1994).

[4] Datta, J.K., A. Banerjee,M. SahaSikdar, S. Gupta and N.K. Mondal: Impact of combined exposure of chemical, fertilizer, bio-fertilizer and compost on growth, physiology and productivity of Brassica campestries in old alluvial soil. J. Environ. Biol., 30(5), 797-800 (2009).

[5] Earanna, N. and R. Govindan:Role of Biofertiliser in mulberry production- A review.Ind. J. Seric.,41 (2), 92-99 (2002).

[6] FatemehZaredost, DavoodHashemabadi, Maryam BarariZiyabari, Ali MohammadiTorkashvand, BehzadKaviani, Maryam JadidSolimandarabi and Mohammad Zarchini: The effect of phosphate biofertilizer (Barvar-2) on the growth of marigold. $J$. Environ. Biol., 35, 439-443 (2014).

[7] Krishnaswamy, S., K. Kumaraj, Vijayaraghavan and K. Kasiviswanathan: New Technology silkworm rearing. Ind. J. Seric.,9, 79-89 (1988).

[8] Mirzakhani, M., M.R. Ardkani, A. Aeene Band, F. Rejali and A.H. Shirani Rad: Response of Spring Safflower to co-inoculation with Azotobacterchroococcumand

Glomusintraradicesunder different levels of nitrogen and phosphorus. American J. Agric. Biol. Sci.,3, 255-261 (2009).

[9] Nagarajan, P., N.B. Radha and G. Obliswami: Influence of biofertilizer application in the mulberry field on economic characters of silkworm BombyxmoriL., Indian J. Seric.,23, 106-109 (1986).

[10] Nair, S.K. and N. Chandra: Effect of Biofertilizer application on growth of Nutmeg (MyristicafragransHoutt.) seedlings. Journal of Agric.,39, 65-66 (2001).
[11] Nithya, D., S.M.Poornima,R.Pazhanimurugan,V.Gopikrishnan, Radhakrishnan,M.DhagiraBhivi and R. Balagurunathan: Influence of biofertilizers and irrigation systems for the growth and yield of mulberry plants. Int. J. Plant, Animal and Environmental Sciences, 1(3), 93-99 (2011).

[12]Rajany, T.: Studies on improving quality in mulberry through biofertilizerAzotobacter in relation to economic characters of silkworm (BombyxmoriL.), M.Sc. (Agri.) Thesis, Tamil Nadu Agricultural University, Coimbatore, (1998).

[13]Rajaram, S.,K. Nongrang,S.K.Mandal, M.K. Ghoshand B.B.Bindroo: Azotobacterchroococcum Mass Culture for Production of Bio-Fertilizer, Its Sustained Efficacy on Nitrogen Fixation and Crop Productivity in Mulberry Garden. Int. J. Computational Engineering Res.,3(3),333-340 (2013).

[14]Ram Rao, D. M. and J.Kodandaramaiah:Effect of VAM fungi on mulberry leaf yieldunder semiarid conditions. Caspian J. Env. Sci.,5(2), 111-117 (2007).

[15] Sharma A.K.: Biofertilizers for sustainable agriculture. Agrobios India Pub., p.407 (2002).

[16] Sharma, K.B.: Evaluation of biofertilizers for establishment of mulberry (Morusalba L.). Sericolgia, 31(2), 222-223 (1987).

[17] Sonwalkar, T.N.: Handbook of Silk Technology. New Delhi: Wiley Eastern Limited(1991).

[18] Sreeramalu, K.R., M. Hanumanthappa, A. Gowda, K.N. Kalyana and N. Jayasheela: Dual inoculation of Azotobacterchroococcumand Glomusfasciculatum improves growth and yield of sunflower under field conditions and saves nitrogen and phosphorous fertilizer application. Environ. Ecol.,18 (2), 380384 (2000).

[19] Srinivasan, E.B.: Preliminary studies on cold reeling of silk (BombyxmoriL.). Indian J. Seric.,21, 53-60 (1980).

[20] Subbarayappa, C.T., S.K. Kenchannagowda, T.V. Muniyappa and Manjunatha: Effect of different sources of nitrogenous fertilizer on the quality of silkworm cocoons. Mysore J. Agric. Sci.,26 (1), 8285 (1992).

[21] Sudhakar, P., G.N. Chattopadhyaya,S.K. Gangwar and J.K. Ghosh: Effect of foliar application of Azotobacter, Azospirillum and Beijerinckia on leaf yield and quality of mulberry (Morusalba). J. Agric. Sci., 34, 227-234 (2000).

[22] SumanKashyap, Satyawati Sharma and Padma Vasudevan. Role of bioinoculants in development of salt-resistant saplings of Morusalba(var. 
sujanpuri) in vivo. Scientia Horticulture, 100, 291307 (2004).
[23] Trivedi, J.K. and P. Bhattacharya: Prospect and limitation of Azotobacterbiofertilizer. Farmer and Parliament, 28, 13-14 (1993).

TABLE.1: TEMPERATURE AND RELATIVE HUMIDITY FOR DIFFERENT LARVAL PERIODS

\begin{tabular}{|c|c|c|}
\hline Larval Instars & Temperature $^{\mathbf{0}} \mathbf{C}$ & Relative Humidity (RH) \\
\hline I instar larvae & $26-28$ & 85 \\
\hline II instar larvae & $26-28$ & 85 \\
\hline III instar larvae & $24-26$ & 80 \\
\hline IV instar larvae & $24-25$ & 75 \\
\hline V instar larvae & $23-24$ & 70 \\
\hline
\end{tabular}

TABLE.2: EFFECT OF BIOFERTILIZER AZOTOBACTER CHROOCOCCUM ON MULBERRY CROP AND ITS EFFECTS ON THE YIELD OF BOMBYX MORI L.

\begin{tabular}{|c|c|c|c|c|c|c|}
\hline \multirow{2}{*}{ Parameters } & \multicolumn{2}{|c|}{ I rearing (30 days) } & \multicolumn{2}{|c|}{ II Rearing (60 days) } & \multicolumn{2}{|c|}{ III Rearing (90 days) } \\
\hline & Control & Treated & Control & Treated & Control & Treated \\
\hline Leaf weight (gm) & $378 \pm 79.90$ & $\begin{array}{c}466 \pm 85.00 \\
(23 \%)^{*}\end{array}$ & $318 \pm 49.34$ & $\begin{array}{c}407 \pm 53.81 \\
(28 \%)^{*}\end{array}$ & $335 \pm 61.90$ & $\begin{array}{c}432 \pm 46.17 \\
(30 \%)^{* *}\end{array}$ \\
\hline Total leaves (kg) & $17.04 \pm 3.03$ & $\begin{array}{c}21.16 \pm 3.75 \\
(22 \%)^{*}\end{array}$ & $16.64 \pm 1.29$ & $\begin{array}{c}19.99 \pm 2.4 \\
(24 \%)^{*}\end{array}$ & $18.01 \pm 1.31$ & $\begin{array}{c}24.21 \pm 2.58 \\
(30 \%)^{*}\end{array}$ \\
\hline $\begin{array}{c}\text { Weight of larvae } \\
(\text { gm) }\end{array}$ & $38.16 \pm 0.53$ & $\begin{array}{c}44.91 \pm 0.82 \\
(19 \%)^{*}\end{array}$ & $37.8 \pm 0.42$ & $\begin{array}{c}45.3 \pm 0.94 \\
(20 \%)^{*}\end{array}$ & $38.3 \pm 0.54$ & $\begin{array}{l}46.1 \pm 0.99 \\
(20 \%)^{* *}\end{array}$ \\
\hline $\begin{array}{c}\text { Weight of cocoon } \\
(\mathrm{gm})\end{array}$ & $18.5 \pm 0.92$ & $\begin{array}{l}22.5 \pm 1.24 \\
(\mathrm{~S} 21 \%)^{*}\end{array}$ & $18.8 \pm 0.96$ & $\begin{array}{c}21.7 \pm 1.10 \\
(24 \%)^{*}\end{array}$ & $19.0 \pm 1.02$ & $\begin{array}{c}23.6 \pm 1.62 \\
(25 \%)^{*} \\
\end{array}$ \\
\hline Shell weight (gm) & $6.48 \pm 0.92$ & $\begin{array}{c}8.42 \pm 0.95 \\
(29 \%)^{*}\end{array}$ & $7.62 \pm 0.83$ & $\begin{array}{l}9.52 \pm 0.96 \\
(24 \%)^{*}\end{array}$ & $8.06 \pm 0.81$ & $\begin{array}{c}11.63 \pm 1.03 \\
(44 \%)^{* *}\end{array}$ \\
\hline $\begin{array}{l}\text { Length of the silk } \\
\text { filament (mts) }\end{array}$ & $687.4 \pm 32.43$ & $\begin{array}{c}741.2 \pm 36.23 \\
(25 \%)^{*}\end{array}$ & $744.2 \pm 41.52$ & $\begin{array}{c}759.9 \pm 42.74 \\
(26 \%)^{*} \\
\end{array}$ & $741.8 \pm 35.68$ & $\begin{array}{c}753.3 \pm 37.09 \\
(27 \%)^{*}\end{array}$ \\
\hline Shell ratio & $17.3 \pm 3.02$ & $\begin{array}{c}18.0 \pm 3.12 \\
(4 \%)^{*}\end{array}$ & $17.7 \pm 3.03$ & $\begin{array}{c}18.3 \pm 3.46 \\
(3 \%)^{* *}\end{array}$ & $17.9 \pm 3.21$ & $\begin{array}{c}19.1 \pm 3.3 \\
(6 \%)^{* *}\end{array}$ \\
\hline $\operatorname{ERR}(\%)$ & $93.30 \pm 3.42$ & $\begin{array}{c}98.8 \pm 3.52 \\
(5 \%)^{*}\end{array}$ & $91.30 \pm 3.16$ & $\begin{array}{c}99.33 \pm 3.71 \\
(8 \%)^{* *}\end{array}$ & $94.60 \pm 3.52$ & $\begin{array}{c}99.7 \pm 3.76 \\
(5 \%)^{* *}\end{array}$ \\
\hline
\end{tabular}

Percentages are given in parentheses
Significant level : $\quad * \mathbf{P}<0.05$ 